\title{
EFFECT OF BIOCONTROL AGENTS AND NATURAL PLANT EXTRACTS AND OILS ON THE GROWTH OF Rhizoctonia solani, A PATHOGEN ON TOMATO, IN VITRO \\ Elsheshtawi, A. M. ; T. E. El-Gazzar**; A. H. AbouTabl* and M. A. Ebid* \\ * Plant Pathology Department, Faculty of Agriculture, Mansoura University, Mansoura, Egypt \\ ** Department of Vegetables and Floriculture, Faculty of Agriculture, Mansoura University, Mansoura, Egypt
}

\begin{abstract}
Survey on damping off and wilt diseases of tomato caused by Rhizoctonia solani was conducted at 6 counties in Dakahlia governorate, Egypt. A higher percentage of disease incidence (DI) was detected in tomato beds in open fields when compared with seedlings produced in plastic trays at commercial nurseries in greenhouses. Disease incidence ranged from $0-18 \%$ in the surveyed fields. The highest DI ratios were found in Bany Ebaid, El-Manzala and Belqas Counties; while lower DI percentages (0-12\%) were recorded in counties of EIMansoura, Talkha and Aga. Data obtained in this study showed high antagonistic effect of Trichoderma viride, $T$. harzianum and $T$. hamatum that caused a significant reduction in the linear growth of $R$. solani ranged from $62.5 \%$ to $72.73 \%$ after 7 days of incubation. Gliocladium roseum had the least inhibition effect of the linear growth of the pathogen (40.91\%). All plant extracts caused significant reduction in the linear growth of $R$. solani, which ranged from $18.89 \%$ to $100 \%$ after 7 days of incubation. Mint, onion, rocket, cinnamon and cabbage extracts caused a complete inhibition of the pathogen growth at 0.25 and 0.50 concentrations. Ginger extract caused inhibition ranged from $36.36 \%$ to $85.56 \%$. Rocket and pepper extracts were ranked the least inhibitors of $R$. solani linear growth.
\end{abstract}

Keywords: Rhizoctonia solani, tomato, biological control, plant extracts, essential oils

\section{INTRODUCTION}

Rhizoctonia solani is a fungal pathogen causing considerable reduction in both yield quality and quantity in tomato grown in the field and in the greenhouse. It causes seedling damping off, root rot and crown rot especially in the Nile Delta. The deleterious damage occurs in all stages of tomato growth especially in seedlings in the nurseries or in fields after transplanting. It is widely spread in many parts of the world, and Egypt as well especially in Dakahlia and the newly reclaimed lands (Abd El-Wahab, 2004 and Morsy, 2005).

Biological control had attracted the interest because of increasing regulations and restrictions against pesticides and also unsuccessful control attempts by other control means. Biological control of soil-borne pathogens by antagonistic microorganisms is promising because these pathogens are difficult to be controlled with fungicides (Moussa et al., 2006 \& 2007). The excessive use of broad spectrum or persistent chemicals might result in soil 
contamination, fungicidal resistance or other harmful effects. Biological control is usually more enduring with no toxic residue in nature's food chains, safe for application, and cheaper in cost (Maloy, 1993). The use of plant extracts, i.e. juice, oil or purified known materials is a new approach that show promising results in controlling certain plant diseases with less environmental pollution (Aly, 2003; Sehajpal et al., 2009). The present investigation was conducted to: 1) survey for the Rhizoctonia stem canker and root-rot diseases in tomato seedlings and plants in the nurseries and open fields in some counties of Dakahlia Governorate, Egypt; 2) isolate, purify and identify the causal microorganisms, 3) determine the effects of different plant extracts and phyto-essential oils on radial growth of $R$. solani in vitro.

\section{MATERIALS AND METHODS}

\section{Survey, isolation, purification and identification of the pathogen:}

Tomato plants showing damping-off disease symptoms were surveyed in tomato nurseries and fields in different counties of Dakahlia governorate, Egypt to record the levels of the disease incidence. Four diseased plants of each disease symptom were collected in plastic bags, brought to the laboratory for isolating the disease-causing fungi including $R$. solani. Isolation was done by picking off mycelial growth from diseased tomato seedlings and plant roots, then transferred to the surface of Potato Dextrose Agar medium (PDA) amended with Rose-Bengal $(0.003 \%)$ and streptomycin sulfate $(0.01$ $\%$ ) in Petri dishes and incubated on $20 \pm 2^{\circ} \mathrm{C}$ for $4-7$ days in complete darkness (Clarkson, et al.2002). $R$. solani was isolated as predominant fungus from all diseased tomato plants and was identified on the typical characteristics as mycelium brownish, septate and forming new growth at right angle with long cell. The above characteristics agreed more closely with Rhizoctonia solani Kuhn. The purified fungal isolates were identified by Dept. of Plant Pathology, Faculty of Agriculture, EL-Mansoura University. PDA slants from isolated fungus were kept in refrigerator on $4^{\circ} \mathrm{C}$ for further studies.

\section{Effect of antagonistic fungal cultures and filtrate.}

Five fungal antagonists of $T$. viride, $T$. harzianum, $T$. hamatum, $G$. roseum, and $G$. virens Isolated from the rhizosphere zones of healthy tomato plants grown in Dakahlia governorate. The inhibitory effects of these antagonistic fungi and its filtrate on radial growth of $R$. solani were studied. Each of the obtained fungal antagonists was grown on PDA for 5-7 days at $\left(25 \pm 2^{\circ} \mathrm{C}\right)$, the fungal pathogen was grown on PDA for $5-7$ days at $\left(20 \pm 2^{\circ} \mathrm{C}\right)$ in darkness. The antagonistic effect of each used antagonist on the pathogen was done through using one disc ( $5 \mathrm{~mm}$. in diameter) of the antagonist facing one disc $(5 \mathrm{~mm}$. in diameter) of the pathogen on the PDA surface and relatively closed to the periphery of each plate. The untreated control treatment was done on the same medium in Petri dishes by growing one disc of the pathogenic fungus in the same place but there was fungal free disc. Three replicates were used. 
Culture filtrates of antagonistic fungi were prepared from liquid cultures that filtrated through filter paper (Whatman's No.1), centrifuged at $12000 \mathrm{rpm}$ for $30 \mathrm{~min}$., and sterilized by using membrane filter of pore size of $0.22 \mu \mathrm{m}$. The resulted filtrates were kept in sterilized dark bottles in refrigerator at $5^{\circ} \mathrm{C}$ until using. Then were mixed with PDA at $48^{\circ} \mathrm{C}$ to obtain concentrations of 0 , 10,25 and $50 \%$, then poured in Petri dishes $(9 \mathrm{~cm}$ diameter) three replicates of each treatment. Plates were inoculated with discs $(5 \mathrm{~mm}$ diameter) from 7 days old culture placed in the center of each plate, then incubated at $20 \pm 2^{\circ} \mathrm{C}$, Average of radial growth was recorded after 7 days compared with the untreated control \% when mycelial growth covered the surface of control treatment. Inhibition of growth was calculated in relation to the growth in the control as described before. All plates were incubated at $\left(20 \pm 2^{\circ} \mathrm{C}\right)$ in dark for 7 days after inoculation; the diameter average of growing zone of the pathogenic the fungus was recorded as described before.

\section{Effect of essential oils and plant extracts.}

Six commercial essential oils; Cinnamon (Cinnamomum zeylanicum), Garlic (Allium sativum); Ginger (Zingiber officinale), Mint (Mentha spicata) Onion (Allium cepae) and Citronella (Pelargonium citrosum) were tested for their antifungal activity at three concentrations $0.25,0.50$ and $0.75 \%(\mathrm{v} / \mathrm{v})$ mixed with PDA medium, after autoclaving with $0.5 \%$ of Tween- $80(\mathrm{v} / \mathrm{v})$ to enhance oil solubility, then the essential oil concentrates were added before solidifying, then poured in sterile Petri dishes $(9 \mathrm{~cm}$ diameter). Three replicates for each concentrate were used. The same procedure was done with seven plant extracts (red onion peels, cabbage, rocket, mint, pepper and cinnamon bark. The extracts were prepared from dry parts were soaked in distilled water at the rate of $1: 2(\mathrm{w} / \mathrm{v})$, then were mixed with PDA at $48^{\circ} \mathrm{C}$ to obtain concentrations of $0,10,25$ and $50 \%$ with $0.5 \%$ of Tween $-80(\mathrm{v} / \mathrm{v})$ to enhance extract solubility. Control treatment was done by mixing PDA with tween-80 only without adding any essential oil. All plates were left for $30 \mathrm{~min}$ to be solidified before inoculation with $5 \mathrm{~mm}$ diameter discs taken from 7 days old culture of the pathogen. Average of radial growth was recorded after 7 days and compared with the untreated control (De-Billerbeck, et al 2001).

The percentage of inhibition was calculated on the basis of growth in the control plates using the expression:

$$
\% \text { Mycelial inhibition }=(X-Y / X) \times 100
$$

Where $X$ and $Y$ are the average diameters of mycelial colonies in control and treated fungal sets.

Statistical analysis:Statistically, the obtained data were subjected to analysis of variance (ANOVA); Gomez and Gomez, (1984); followed by Duncan's multiple range tests to compare means (Duncan, 1955).

\section{RESULTS}

\section{Survey of disease incidence}

Data presented in Table (1), indicated percentages of fungi isolated from tomato seedlings and plants. Data are presented as value and its percentage between brackets. 
Elsheshtawi, A. M. et al. 
Samples of seedlings and plants from six counties of EL-Mansoura, Talkha, El-Manzalla, Bany Ebeid, Belqas and Aga at Dakahlia governorate were assessed and total numbers of fungi recovered from each sample were varied among seedlings from nurseries and plants from tomato fields. The total number ranged from 11 to 20 infected pieces out of 100 pieces assessed from each sample. Fungi recovered on PDA agar plates were $R$. solani, Fusarium spp, Pythium spp, Trichoderma spp, Penicillium and few other saprophytic fungi. $R$. solani was recovered in all plated plant pieces from all samples represent all six counties in Dakahlia governorate. Percentages of $R$. solani were varied in seedling samples and plants; the high percentage of $R$. solani was $27.27 \%$ in seedling samples from ElMansoura county and $42.86 \%$ in mature plant samples from Bany Ebaid county while the lower percentage $(14.29 \%)$ was recovered from seedling samples from Talkha county and $15 \%$ in tomato mature plant samples from Aga county. R. solani was followed by Fusarium spp; Pythium spp, Rhizopus $\mathrm{spp}$ in higher percentage while Sclerotium rolfsii, Trichoderma spp, Penicillium and other fungi were detected in moderate to lower percentages.

\section{Effect of antagonistic fungal cultures and filtrate.}

Data presented in Table (2) showed significant differences among treatments of antagonism between each of the five fungal species and $R$. solani. The antagonistic effect of the five fungi was determined after 3 periods of incubation (3, 5 and 7 days). T. viride, T. harzianum and T. hamatum caused a significant reduction in linear growth of $R$. solani ranged from $62.5 \%$ to $72.73 \%$ as inhibition percentages after 7 days of incubation. G. virens and $G$. roseum had also significant effect to reduce the linear growth of the pathogen but $G$. virens was more or less like Trichoderma species but $G$. roseum showed the lowest effect in reduction of linear growth of the pathogen $(5.2 \mathrm{~cm}=40.91 \%$ inhibition). In comparison with control treatment $(R$. solani) the highest reductions in $R$. solani colony linear growth after 7 days were 3.3, $2.4,2.4,2.4$ and $5.2 \mathrm{~cm}$ compared with the control linear growth $(8.8 \mathrm{~cm})$ after treatment with the previous five fungal species, respectively

Also; Data presented in Table (2) showed that culture filtrates of five fungal species of $T$. viride, $T$. harzianum, $T$. hamatum, $G$. virens, $G$. roseum had a significant differences among treatments of antagonism between each of the five fungal species and $R$. solani. The antagonistic effect of the five fungal filtrates were determined for each dilution after 7days incubation for the fungal filtrates and $24 \mathrm{hr}$ incubation for bacterial cultures filtrates against $R$. solani. Culture filtrates of $T$. viride, $T$. harzianum and $T$. hamatum caused a significant reduction ranged from $1.2 \mathrm{~cm}$ (inhibition $=86.67 \%$ ) to $1.5 \mathrm{~cm}$ (inhibition $=83.33 \%$ in linear growth of $R$. solani compared with control (8.6 to $9 \mathrm{~cm}$ ) in all dilutions 10, 25 and $50 \%$. However; the higher significant reduction among Trichoderma species was observed in $T$. viride in the treatments of culture filtrates, 10 and $25 \%$ but these differences were nonsignificant among these isolates at $50 \%$ dilution. G. virens and G. roseum had also significant effect to reduce the linear growth of the pathogen but $G$. roseum had more effect at $50 \%$ dilutions (inhibition $=97.98 \%$ ). In general; data indicated that culture filtrates of all tested fungi were more effective in their toxic effect and suppression of $R$. solani by increasing their 
Elsheshtawi, A. M. et al.

concentration or reduction of the dilution compared with the control treatment (without culture filtrate).

Table (2): Effect of fungal antagonist cultures and its filtrates on radial growth of $R$. solani

\begin{tabular}{|c|c|c|c|c|}
\hline \multirow{3}{*}{\multicolumn{2}{|c|}{ Treatments ${ }^{\star * *}$}} & \multirow{2}{*}{\multicolumn{3}{|c|}{$\frac{R \text {. solani radial growth measurement (cm) (inhibition \%) }}{\text { Incubation period (day) }}$}} \\
\hline & & & & \\
\hline & & \multirow{2}{*}{$\begin{array}{c}\text { After } 3 \text { days } \\
2.8 \mathrm{ab}^{*}(3.45 \%)^{\star *}\end{array}$} & \multirow{2}{*}{$\begin{array}{c}\text { After } 5 \text { days } \\
2.9 \mathrm{c}(45.28 \%)\end{array}$} & \multirow{2}{*}{$\begin{array}{c}\text { After } 7 \text { days } \\
3.3 \mathrm{c}(62.50 \%)\end{array}$} \\
\hline & C & & & \\
\hline 1. Viride & $\mathbf{F}$ & $2.2 \mathrm{~d}(75.28 \%)$ & 3.6 b (58.14\%) & $1.5 \mathrm{c}(83.33 \%)$ \\
\hline \multirow{2}{*}{ T. harzianum } & C & $2.4 \mathrm{c}(17.24 \%)$ & 2.3 e $(56.60 \%)$ & $2.4 \mathrm{~d}(72.73 \%)$ \\
\hline & $\mathbf{F}$ & 2.6 c $(70.79 \%)$ & 2.6 c $(69.77 \%)$ & 1.2 c (86.67\%) \\
\hline \multirow{2}{*}{ T. hamatum } & C & $2.4 \mathrm{c}(17.24 \%)$ & $2.4 \mathrm{~d}(54.71 \%)$ & $2.4 \mathrm{~d}(72.73 \%)$ \\
\hline & $\mathbf{F}$ & 1.2 e $(86.52 \%)$ & $1.8 \mathrm{~d}(79.07 \%)$ & 1.2 c (86.67\%) \\
\hline \multirow[b]{2}{*}{ G. virens } & C & $2.5 \mathrm{c}(13.79 \%)$ & $2.4 \mathrm{~d}(54.71 \%)$ & $2.4 \mathrm{~d}(72.73 \%)$ \\
\hline & $\mathbf{F}$ & 3.2 b (64.05\%) & 0.3 e $(96.51 \%)$ & 2.2 b $(75.56 \%)$ \\
\hline \multirow{2}{*}{ G. roseum } & C & $2.7 \mathrm{~b}(6.89 \%)$ & $4.9 \mathrm{~b}(7.55 \%)$ & $5.2 \mathrm{~b}(40.91 \%)$ \\
\hline & $\mathbf{F}$ & 2.6 c $(70.79 \%)$ & $1.3 \mathrm{~d}(84.88 \%)$ & $0.2 \mathrm{~d}(97.78 \%)$ \\
\hline \multirow{2}{*}{ Control } & C & 2.9 a $(0 \%)$ & 5.3 a $(0 \%)$ & $8.8 \mathrm{a}(0 \%)$ \\
\hline & $\mathbf{F}$ & 8.9 a (0 \%) & 8.6 a (0 \%) & $9.0 \mathrm{a}(0 \%)$ \\
\hline L.S.D. & & 0.36 & 0.51 & 0.35 \\
\hline
\end{tabular}

Letters followed the value are Duncan's statistical analysis for differences among values means. $^{* *}$ values between brackets are percentage growth inhibition. ${ }^{* \star *} \mathrm{C}=$ fungal culture; $F=$ fungal culture filtrate.

\section{Effect of essential oils on radial growth of $R$. solani}

Data presented in Table (3), indicated that six different essential oils of Onion, Citronella, Cinnamon, Mint, Garlic and Ginger were used in control experiment to examine their ability to suppress it's the growth of $R$. solani and to be used as safe chemicals for the control of $R$. solani in the subsequent greenhouse and field experiments. Three concentrations of the essential oils $(0.25,0.50$ and 0.75$)$ were use in this experiment. Significant differences among treatments of the tested oils and $R$. solani (control). The fungicidal effect of the oils was determined after 7 days. All oils caused a significant reduction in linear growth of $R$. solani ranged from $17.05 \%$ to $100 \%$ as inhibition percentages after 7 days of incubation. Citronella, Cinnamon and Mint oils were the best oils tested and caused a complete inhibition at 0.50 and 0.75 concentrations followed by onion oil that caused inhibition percentages ranged from $22.35 \%$ to $52.22 \%$. Garlic and ginger oils had the lowest effect compared with other oils.

Effect of plant extracts on radial growth of $R$. solani

Data presented in Table (4), indicated that six different plant extracts of Mint, Onion, Rocket, Cinnamon, Cabbage, Garlic and Pepper were used in control experiment to examine their ability to suppress the growth of $R$. solani and to be used as safe compounds for the control of $R$. solani in the subsequent greenhouse and field experiments. Three concentrations of the essential oils $(0.10,0.25$ and 0.50$)$ were used in this experiment. Significant differences among treatments of the tested oils and $R$. solani (control). The fungicidal effect of oils was determined after 7 days. All plant extracts caused significant reduction in linear growth of $R$. solani ranged from $18.89 \%$ to 
$100 \%$ as inhibition percentages after 7 days of incubation. Mint, Onion, Rocket, Cinnamon and Cabbage plant extracts were the best oils tested and caused a complete inhibition at 0.25 and 0.50 concentrations. Ginger extract that caused inhibition percentages ranged from $36.36 \%$ to $85.56 \%$. Rocket and Pepper plant extracts were ranked the lowest in percentages of $R$. solani linear growth inhibition. The maximum inhibitions were caused by Rocket and Pepper extracts at concentration $0.5 \%$ were $68.89 \%$ and $74.44 \%$; respectively.

Table (3): Effect of essential oils on radial growth of $R$. solani

\begin{tabular}{|c|c|c|c|}
\hline \multirow{3}{*}{ Oil Treatments } & \multicolumn{3}{|c|}{$\begin{array}{l}\text { R. solani radial growth measurement }(\mathrm{cm}) \\
\text { (Inhibition \%) }\end{array}$} \\
\hline & \multicolumn{3}{|c|}{ Essential oils concentration } \\
\hline & 0.25 & 0.50 & 0.75 \\
\hline Onion & $\begin{array}{c}6.6 \mathbf{~ c} \\
(22.35 \%)\end{array}$ & $\begin{array}{c}\mathbf{5 . 2} \mathbf{c} \\
(42.22 \%)\end{array}$ & $\begin{array}{c}4.3 \mathrm{~d} \\
(52.22 \%)\end{array}$ \\
\hline Citronella & $\begin{array}{c}0.0 \text { e } \\
(100 \%)\end{array}$ & $\begin{array}{c}\mathbf{0 . 0} \mathbf{e} \\
(100 \%)\end{array}$ & $\begin{array}{l}\mathbf{0 . 0} \mathbf{d} \\
(100 \%)\end{array}$ \\
\hline Cinnamon & $\begin{array}{c}\mathbf{0 . 0} \mathbf{e} \\
(100 \%)\end{array}$ & $\begin{array}{c}\mathbf{0 . 0} \mathbf{e} \\
(100 \%)\end{array}$ & $\begin{array}{c}\mathbf{0 . 0} \mathbf{d} \\
(100 \%)\end{array}$ \\
\hline Mint & $\begin{array}{c}2.5 \mathbf{d} \\
(71.59 \%)\end{array}$ & $\begin{array}{c}\mathbf{0 . 0} \mathbf{e} \\
(100 \%)\end{array}$ & $\begin{array}{c}0.0 \text { d } \\
(100 \%)\end{array}$ \\
\hline Garlic & $\begin{array}{c}7.3 \mathbf{b} \\
(17.05 \%)\end{array}$ & $\begin{array}{c}6.2 \mathbf{b} \\
(31.11 \%)\end{array}$ & $\begin{array}{c}5.3 \mathrm{c} \\
(41.11 \%) \\
\end{array}$ \\
\hline Ginger & $\begin{array}{c}8.5 \mathrm{a} \\
(3.41 \%)\end{array}$ & $\begin{array}{c}7.3 \mathbf{b} \\
(18.89 \%)\end{array}$ & $\begin{array}{c}\mathbf{6 . 2} \mathbf{b} \\
(31.11 \%)\end{array}$ \\
\hline Control & $\begin{array}{l}8.8 \mathrm{a} \\
(0 \%)\end{array}$ & $\begin{array}{l}9.0 \mathrm{a} \\
(0 \%)\end{array}$ & $\begin{array}{l}9.0 \mathrm{a} \\
(0 \%)\end{array}$ \\
\hline L.S.D. & 0.39 & 0.38 & 0.39 \\
\hline
\end{tabular}

Table (4): Effect of plant extracts on radial growth of $R$. solani.

\begin{tabular}{|c|c|c|c|}
\hline \multirow{3}{*}{ Plant extracts Treatments } & \multicolumn{3}{|c|}{$\begin{array}{l}\text { R. solani radial growth measurement }(\mathrm{cm}) \\
\text { (Inhibition \%) }\end{array}$} \\
\hline & \multicolumn{3}{|c|}{ Plant extract concentration } \\
\hline & 0.10 & 0.25 & 0.50 \\
\hline Mint & $\begin{array}{c}2.3 \mathrm{c} \\
(73.86 \%)\end{array}$ & $\begin{array}{c}\mathbf{0 . 0} \mathbf{f} \\
(100 \%)\end{array}$ & $\begin{array}{c}\mathbf{0 . 0} \mathbf{c} \mathbf{c} \\
(100 \%)\end{array}$ \\
\hline Onion & $\begin{array}{c}2.3 \mathrm{c} \\
(73.86 \%)\end{array}$ & $\begin{array}{c}1.3 \mathrm{e} \\
(85.56 \%)\end{array}$ & $\begin{array}{c}\mathbf{0 . 0} \mathbf{c} \\
(100 \%)\end{array}$ \\
\hline Rocket & $\begin{array}{c}7.3 \mathbf{a} \\
(18.89 \%)\end{array}$ & $\begin{array}{c}4.8 \mathrm{~b} \\
(45.46 \%)\end{array}$ & $\begin{array}{c}2.8 \mathbf{a} \\
(68.89 \%)\end{array}$ \\
\hline Cinnamon & $\begin{array}{c}3.0 \mathrm{c} \\
(65.91 \%)\end{array}$ & $\begin{array}{c}\mathbf{0 . 0} \mathbf{f} \\
(100 \%)\end{array}$ & $\begin{array}{c}\mathbf{0 . 0} \mathbf{c} \\
(100 \%)\end{array}$ \\
\hline Cabbage & $\begin{array}{c}3.3 \mathbf{c} \\
(63.33 \%)\end{array}$ & $\begin{array}{c}1.3 \mathbf{d} \\
(85.23 \%)\end{array}$ & $\begin{array}{c}\mathbf{0 . 0} \mathbf{c} \\
(100 \%)\end{array}$ \\
\hline Ginger & $\begin{array}{c}5.6 \mathbf{a} \\
(36.36 \%)\end{array}$ & $\begin{array}{c}2.3 \mathbf{d} \\
(74.44 \%)\end{array}$ & $\begin{array}{c}1.3 \mathbf{b} \\
(85.56 \%)\end{array}$ \\
\hline Pepper & $\begin{array}{c}4.3 \mathbf{b} \\
(52.22 \%)\end{array}$ & $\begin{array}{c}2.5 \mathrm{c} \\
(71.59 \%)\end{array}$ & $\begin{array}{c}2.3 \mathrm{a} \\
(74.44 \%)\end{array}$ \\
\hline Control & $\begin{array}{l}8.8 \text { a } \\
(0 \%)\end{array}$ & $\begin{array}{l}9.0 \mathrm{a} \\
(0 \%)\end{array}$ & $\begin{array}{l}9.0 \text { a } \\
(0 \%)\end{array}$ \\
\hline L.S.D. & 0.39 & 0.66 & 0.54 \\
\hline
\end{tabular}




\section{DISCUSSION}

The present work deals with the root rot and stem canker of tomato plants caused by soil borne pathogens in which $R$. solani represent the major causal pathogen of these disease symptoms in tomato nurseries and fields under soil conditions of Dakahlia governorate, Egypt. One of the main obstacles to the development of tomato production is the spread of tomato fungal diseases that affect production negatively in relation to soaring consumption rates due to rapid population growth. It is well known that, several fungal diseases attack tomato plants during all stages of growth causing a considerable reduction in both yield quality and quantity. Dampingoff, root rots and wilting are among the important diseases. Root rot pathogens such as Rhizoctonia solani and Sclerotium rolfsii attack the roots and stem base of tomato (AbdEI-Wahab, 2004 and Morsy, 2005). The survey results showed that there is a rapid outbreak of $R$. solani causes damping off or root rot infection disease symptoms in all tomato seedlings beds and fields in counties surveyed at Dakahlia governorate. In the beds or greenhouses for seedling production at six counties of ELMansoura, Talkha, EIManzalla, Bany Ebeid, Belqas and Aga there were a varied disease symptoms showed and recorded as disease incidence. The higher ratios were observed in seedlings produced in beds at field soil while the lower ratios were found in seedlings produced in foam containers inside commercial tomato greenhouses for seedling production. Disease symptoms of root rot in tomato plants collected from fields were ranged from $0 \%$ to $18 \%$. The high percentages up to $18 \%$ were observed in plants grown in fields at Bany Ebaid, El-Manzala and Belqas Counties while the lower percentages $(0-12 \%)$ were recorded in counties of ElMansoura, Talkha and Aga. These results were in agreement with those obtained by Shehata (2001) who found that $R$. solani caused the highest percentage of pre-emergence damping-off and gave the lowest of healthy survival plants compared with the other fungi. Also; Abd-El-Wahab (2004) and Zaghloul et al., (2008) found that $R$. solani, F. oxysporum f.sp lycopersici isolates, and S. rolfsii were the most aggressive fungal isolates.

Data obtained in the current study showed the antagonistic effect of the five fungi was determined after 3 periods of incubation ( 3,5 and 7 days). $T$. viride, $T$. harzianum and $T$. hamatum caused a significant reduction in linear growth of $R$. solani ranged from $62.5 \%$ to $72.73 \%$ as inhibition percentages after 7 days of incubation. G. virens and G. roseum had also significant effect to reduce the linear growth of the pathogen but $G$. virens was more or less like Trichoderma spp but $G$. roseum showed the lowest effect in reduction of linear growth of the pathogen $(5.2 \mathrm{~cm}=40.91 \%$ inhibition). These results are in harmony with those reported by Durman et al.(1999) who found that $T$. harzianum and $T$. viride were more effective than other antagonistic fungi when tested in the greenhouse as seed treatments against $R$. solani and F. oxysporum. Also, Niknejad et al.(2000) and Tsahouridou and Thanassoulopoulos (2002) found that the lower percentage of root-rot and wilting disease severity of tomato plants were obtained when 
the soil was first infested with $T$. harzianum and $T$. viride, and then reinfested with the highly pathogenic isolate of the $R$. solani. T. harzianum decreased the population of $F$. oxysporum f.sp lycopersici in rhizosphere, while the population of $T$. harzianum increased up to the 4th week after transplanting.

Sabaratnam and Traquair (2002) and Abd-El-Wahab (2004) found that tomato seed treatment with $T$. harzianum, T. viride, G. virens, B. subtilis, Ps. fluorescens, and Streptomyces recorded the maximum protection against pre- and post-emergence damping-off caused by $F$. oxysporum f.sp lycopersici, $R$. solani and $S$. rolfsii and reduced the disease incidence. Different authors discussed and explained the antifungal activity of $T$. harzianum and $T$. viride due to several means i.e., Mycoparasitism (a complex process), Trichoderma spp. attach to the host (pathogen) and can coil around it and suppress growth by endolysis in protoplasm or form Appressoria on the host surface and attachment is mediated by the binding of carbohydrates in the Trichoderma cell wall to lectins on the target fungus (Shaigan, et al.2008).

Essential oils used in control experiment of $R$. solani. All oils caused a significant reduction in linear growth of $R$. solani ranged from $17.05 \%$ to $100 \%$ as inhibition percentages after 7 days of incubation. Citronella, Cinnamon and Mint oils were the best oils tested and caused a complete inhibition at 0.50 and 0.75 concentrations followed by onion oil that caused inhibition percentages ranged from $22.35 \%$ to $52.22 \%$. Garlic and ginger oils had the lowest effect compared with other oils. Plant extracts used in control experiment of $R$. solani showed differences in which all plant extracts caused a significant reduction in linear growth of $R$. solani ranged from $18.89 \%$ to $100 \%$ as inhibition percentages after 7 days of incubation. Mint, Onion, Rocket, Cinnamon and Cabbage plant extracts were the best oils tested and caused a complete inhibition at 0.25 and 0.50 concentrations. Ginger extract that caused inhibition percentages ranged from $36.36 \%$ to $85.56 \%$. Rocket and Pepper plant extracts were ranked the lower in percentage of $R$. solani linear growth inhibition. This results in agreement with the results of many authors who reported the antifungal activity of cinnamon oil against plant pathogenic fungi Ranasinghe et al., 2002; reported that oil of cinnamon inhibited the radial growth and spore germination of $F$. oxyasporum, Aspergillus flavus, Colletotrichum musae and F. proliferation. This high antifungal activity of cinnamon oil may be attributed to be presence of some active compounds such as Eugenol (the main compound of cinnamon oil), benzyl alcohol, cinnamic acid, cinnamyl acetate, 4-hydroxybenzaldehyde and salicylaldehyde, as well as two d-phenothrin pyrethrum and cinnamaldhyde (Young-Cheol Yang et al., 2005). Several authors reported similar results; Anil Sehajpal et al (2009); found that antifungal effect of 44 plant extracts and 8 plant oils against the pathogen $R$. solani were evaluated by disc diffusion method. Out of 44 plants tested, 36 plant extracts showed varied degree of antimicrobial effect at different concentrations against the pathogen. Jularat Udomsilp (2009); Reported that in vitro study aimed to evaluate the mycelium growth and spore germination inhibition properties of essential oils. The experiments results showed antifungal properties, on both mycelium growth and spore germination, for rice pathogenic fungi. These 
properties were dependent on plant and fungal species, concentration and the testing conditions.

\section{REFERENCES}

Abd-El-Wahab, G. M. (2004): Integrated disease management of some root diseases in tomato plants. Ph.D. Thesis Fac. of Agric. Damanhour, Alexandria Univ., Egypt.

Aly, M. A. A. (2003). Studies on some diseases of cucumber under protective cultivation. M.Sc. thesis, Faculty of Agriculture, Zagazig University (162 pp).

Anil Sehajpal, Saroj Arora and Parminder Kaur (2009). Evaluation of plant extracts against Rhizoctonia solani causing sheath blight of rice. The Journal of Plant Protection Sciences, 1(1) : 25-30, 200925.

Clarkson, J. P.; Payne, T.; Mead, A. and Whipps, J. M. (2002). Selection of fungal biological control agents of Sclerotium cepivorum for control of white rot by sclerotial degradation in a UK soil. Plant Pathology 51 (6), 735-745.

De-Billerbeck, V.G. ;Roques.C.G. ; Bessière, J. M. ; Fonvieille, J.L. and Dargent, R.(2001). Effects of Cymbopogon nardus (L.) W. Watson essential oil on the growth and morphogenesis of Aspergillus niger. Canada. J. Microbial. 47: 9-17 (2001).

Duncun, D. B. (1955). Multiple ranges and multiple $F$ test. Biometrics11:1-42.

Durman, S.; Menendez, A. and Godeos, A. (1999): Evaluation of Trichoderma spp. as antagonist of Rhizoctonia solani in vitro and as biocontrol of greenhouse tomato plants. Revista Argentina de Microbiologia, 31: $13-18$.

Gomez KA, Gomez AA (1984). Statistical Procedures for Agricultural Research. A. Wiley-Interscience Publication. New York, p. 678.

Jularat Udomsilp, Apinya Piyo, Peerayot Khang-Khun and Pitipong Thobunluepop (2009). Antifungal properties of essential oils from Thai medical plants against rice pathogenic fungi. Asian. J. Food Ag-Ind. 2009, Special Issue, S24-S30

Maloy, O.C. (1993). Plant disease control (principles and practice). John Wiley \& Sons, Inc. New York, Chester, Brisbane, Toronto, Singapore.

Morsy, M. Ebtsam. (2005): Role of growth promoting substances producing microorganisms on tomato plant and control of some Root Rot fungi. Ph.D. Thesis, Fac. of Agric. Ain shams Univ., Cairo.

Moussa, A. Lobna; Ebtsam, M. Morsy; Abeer, M.A. Shaltout and Soheir, S. Fahmy. (2007): efficiency of some bacterial strains for controlling limb rot diseases of peanut in sandy soil. 12th conference of Microbiology, Cairo, Egypt, March 18-20, 2007.

Moussa, A. Lobna; Fahmy, S. Soheir and Shaltout, M. A. Abeer. (2006): Evaluation of some bacterial isolates and compost tea for Biocontrolling Macrophomina Phaseolina and sclerotium Rolfsii infected sunflower. Egypt. J. Agric. Res., 84(5) 1331- 1344. 
Niknejad, M.; Sharfi-Tehani, A. and Okhovat, M. (2000); Effect of antagonistic fungi Trichoderma spp. on the control of Fusarium wilt of tomato caused Fusarium oxysporum f.sp lycopersici under greenhouse conditions. Iranian Journal of Agriculture Science, 1: 31 - 37.

Ranasinghe, L.; B. Jayawarden and K. Abeywickrama. 2002. Fungicidal activity of essential oils of Cinnamomum zeylanicum and Syzygium aromaticum Merr ET L.M.Perry against crown rot and anthracnose pathogens isolated from banana. Letters in Applied Microbiology 35:208-211.

Sabaratnam, S. and Traquair, J.A. (2002): Formulation of a Streptomyces as a biocontrol agent for the suppression of Rhizoctonia damping-off in tomato Transplants. Biological Control, 23: 245-253.

Shaigan, M.A., C.M. (2008). Competitiveness of a genetically engineered strain of Trichoderma virens. Mycopathologia. 166(1):51-9, $2008 \mathrm{Jul}$.

Shehata, M.M. (2001): Studies on tomato root-rot diseases and their control. M.Sc. Thesis. Department of Agricultural Botany Fac. of Agric. ALAzhar Univ., Egypt.

Tsahouridou, P.C. and Thanassoulopoulos, C.C. (2002): Proliferation of Trichoderma koningii in the tomato rhizosphere and the suppression of damping-off by Sclerotium rolfsii . Soil Biology and Biochemistry, 34:767-776.

Young-Cheol Yangc, Hoi-Seon Leea, C, J. M. Clarkb,c, and Young-Joon Ahnc (2005). Insecticidal Activity of Plant Essential Oils Against Pediculus humanus capitis (Anoplura: Pediculidae). Journal of Medical Entomology 41(4):699-704.

Zaghloul, R.A., Neweigy,N.A., Hanafy1, E. A. and Khalifa, A. (2008). Effectiveness of biocontrolagents against tomato soil borne pathogens. Third Environment Conference, Faculty of Science, Zagazig Univ., 2008, $123-142$ 
Elsheshtawi, A. M. et al.

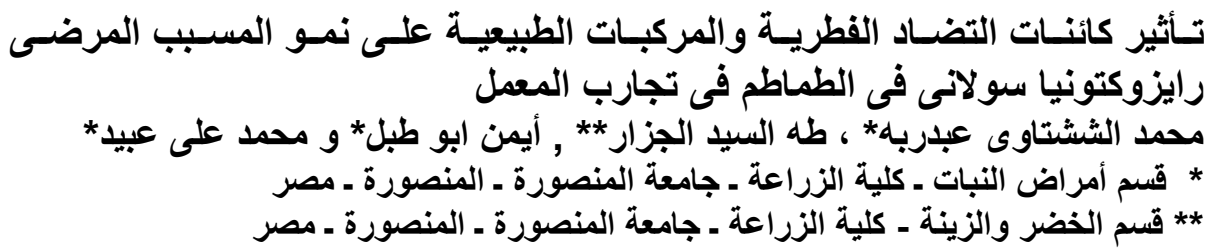

تم استخدام عدد خمسة من الفطريات التضادية المستخدمة فى المقاومة الحيوية للمسببات

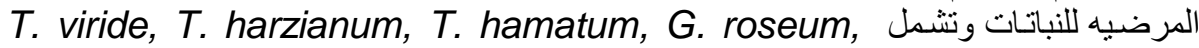
و and G. virens

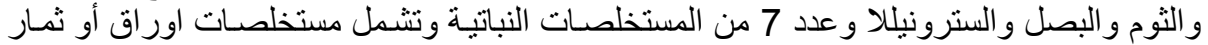

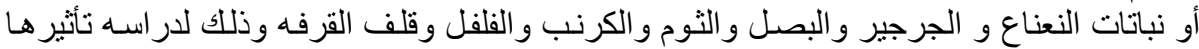

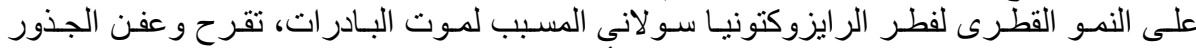

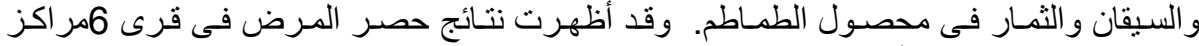

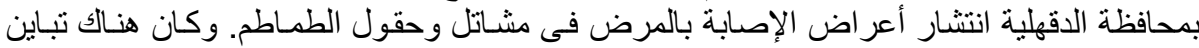

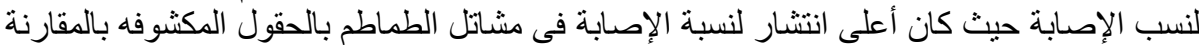

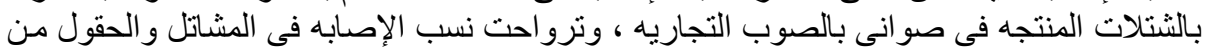

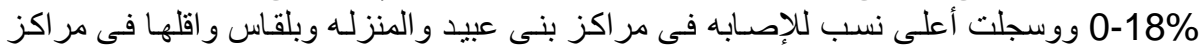

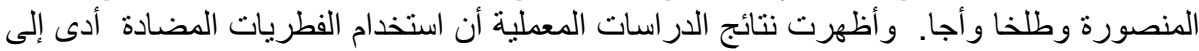
حدوث نقص واضح فى النمو القطرى للفطر المسبب للمرض تراول

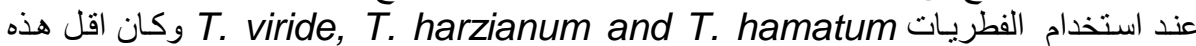
الفطريات المضادة فى التأثير فطر G. virens . كما أظهرت نتائج التجارب المعطلية كفاءة وفعالية

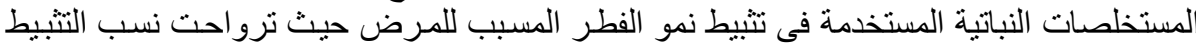

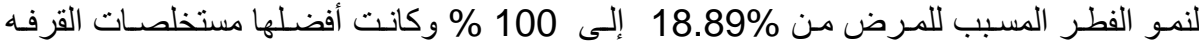
و النعناع (100\%) ثم البصل والكرنب (85\%) و أقلها مستخلصـات الجرجير و الفلفل (69 - 75

كلية الزراعة - جامعة المنصورة كلية الزراعة - جامعة كفر الثيخ

قام بتحكيم البحث

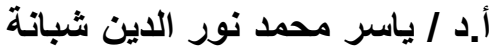
أ.د / السيد فهمي علي مشعل فئل الديان 
Table (1): Common dominant fungi in tomato seedlings and plants collected from fields in different location at Dakahlia governorate counties.

\begin{tabular}{|c|c|c|c|c|c|c|c|c|c|c|c|c|}
\hline \multirow{3}{*}{ Isolated fungi } & \multicolumn{12}{|c|}{ Percentages of fungi isolated from infected tomato seedlings and plants roots } \\
\hline & \multicolumn{2}{|c|}{ Al-Mansoura } & \multicolumn{2}{|c|}{ Talkha } & \multicolumn{2}{|c|}{ Al-Manzalla } & \multicolumn{2}{|c|}{ Bany Ebaid } & \multicolumn{2}{|c|}{ Belqas } & \multicolumn{2}{|c|}{ Aga } \\
\hline & Seedlings & Plants & Seedlings & Plants & Seedlings & Plants & Seedlings & Plants & Seedlings & Plants & Seedlings & Plants \\
\hline R. Solani & $\begin{array}{c}3^{*} \\
(27.27)^{\star \star}\end{array}$ & $\begin{array}{c}4 \\
(25.00)\end{array}$ & $\begin{array}{c}2 \\
(14.29)\end{array}$ & \begin{tabular}{|c|}
3 \\
$(17.65)$
\end{tabular} & $\begin{array}{c}2 \\
16.67)\end{array}$ & $\begin{array}{c}3 \\
(17.65)\end{array}$ & $\begin{array}{c}2 \\
(15.38)\end{array}$ & $\begin{array}{c}6 \\
(42.86)\end{array}$ & $\begin{array}{c}4 \\
(21.05)\end{array}$ & \begin{tabular}{|c|}
4 \\
$(21.05)$ \\
\end{tabular} & $\begin{array}{c}3 \\
(25.00)\end{array}$ & $\begin{array}{c}3 \\
(15.00)\end{array}$ \\
\hline $\begin{array}{l}\text { Fusarium } \\
\text { spp }\end{array}$ & $\begin{array}{c}1 \\
(9.09)\end{array}$ & $\begin{array}{c}2 \\
(12.50)\end{array}$ & $\begin{array}{c}1 \\
(7.14)\end{array}$ & $\begin{array}{c}3 \\
(17.65)\end{array}$ & $\begin{array}{c}0 \\
(0.00)\end{array}$ & $\begin{array}{c}4 \\
(23.53\end{array}$ & $\begin{array}{c}0 \\
(0.00)\end{array}$ & $\begin{array}{c}1 \\
(7.14)\end{array}$ & $\begin{array}{c}0 \\
(0.00)\end{array}$ & $\begin{array}{c}2 \\
(10.53) \\
\end{array}$ & $\begin{array}{c}1 \\
(8.33)\end{array}$ & $\begin{array}{c}4 \\
(20.00)\end{array}$ \\
\hline Pythium spp & $\begin{array}{c}0 \\
(0.00)\end{array}$ & $\begin{array}{c}1 \\
(6.25)\end{array}$ & $\begin{array}{c}1 \\
(7.14)\end{array}$ & $\begin{array}{c}0 \\
(0.00)\end{array}$ & $\begin{array}{c}1 \\
(8.33)\end{array}$ & $\begin{array}{c}2 \\
(11.76\end{array}$ & $\begin{array}{c}1 \\
(7.69)\end{array}$ & $\begin{array}{c}0 \\
(0.00)\end{array}$ & $\begin{array}{c}2 \\
(10.53)\end{array}$ & $\begin{array}{c}1 \\
(5.26)\end{array}$ & $\begin{array}{c}0 \\
(0.00)\end{array}$ & $\begin{array}{c}1 \\
(5.00)\end{array}$ \\
\hline $\begin{array}{l}\text { Sclerotium } \\
\text { rolfsii }\end{array}$ & $\begin{array}{c}0 \\
(0.00)\end{array}$ & $\begin{array}{c}1 \\
(6.25)\end{array}$ & $\begin{array}{c}0 \\
(0.00)\end{array}$ & $\begin{array}{c}1 \\
(5.88)\end{array}$ & $\begin{array}{c}0 \\
(0.00)\end{array}$ & $\begin{array}{c}0 \\
(0.00)\end{array}$ & $\begin{array}{c}1 \\
(7.69)\end{array}$ & $\begin{array}{c}2 \\
(14.29)\end{array}$ & $\begin{array}{c}0 \\
(0.00)\end{array}$ & $\begin{array}{c}1 \\
(5.26)\end{array}$ & $\begin{array}{c}0 \\
(0.00)\end{array}$ & $\begin{array}{c}2 \\
(10.00)\end{array}$ \\
\hline $\begin{array}{l}\text { Rhizopus } \\
\text { spp }\end{array}$ & $\begin{array}{c}3 \\
(27.27)\end{array}$ & $\begin{array}{c}1 \\
(6.25)\end{array}$ & $\begin{array}{c}2 \\
(14.29)\end{array}$ & $\begin{array}{c}4 \\
(23.53)\end{array}$ & $\begin{array}{c}2 \\
(16.67)\end{array}$ & $\begin{array}{c}2 \\
(11.76) \\
\end{array}$ & $\begin{array}{c}2 \\
(15.38) \\
\end{array}$ & $\begin{array}{c}2 \\
(14.29) \\
\end{array}$ & $\begin{array}{c}4 \\
(21.05) \\
\end{array}$ & $\begin{array}{c}3 \\
(15.79) \\
\end{array}$ & $\begin{array}{c}2 \\
(16.67) \\
\end{array}$ & $\begin{array}{c}3 \\
(15.00) \\
\end{array}$ \\
\hline $\begin{array}{l}\text { Trichoderma } \\
\text { spp }\end{array}$ & $\begin{array}{c}1 \\
(9.09)\end{array}$ & $\begin{array}{c}3 \\
(18.75)\end{array}$ & $\begin{array}{c}1 \\
(7.14)\end{array}$ & $\begin{array}{c}2 \\
(11.76)\end{array}$ & $\begin{array}{c}0 \\
(0.00)\end{array}$ & $\begin{array}{c}2 \\
(11.76)\end{array}$ & $\begin{array}{c}1 \\
(7.69)\end{array}$ & $\begin{array}{c}0 \\
(0.00)\end{array}$ & $\begin{array}{c}2 \\
(10.53)\end{array}$ & $\begin{array}{c}1 \\
(5.26)\end{array}$ & $\begin{array}{c}1 \\
(8.33)\end{array}$ & $\begin{array}{c}3 \\
(15.00)\end{array}$ \\
\hline $\begin{array}{l}\text { Pencillium } \\
\text { spp }\end{array}$ & $\begin{array}{c}1 \\
(9.09) \\
\end{array}$ & $\begin{array}{c}2 \\
(12.50) \\
\end{array}$ & $\begin{array}{c}3 \\
(21.43) \\
\end{array}$ & $\begin{array}{c}1 \\
(5.88) \\
\end{array}$ & $\begin{array}{c}2 \\
(16.67) \\
\end{array}$ & $\begin{array}{c}1 \\
(5.88) \\
\end{array}$ & $\begin{array}{c}2 \\
(15.38) \\
\end{array}$ & $\begin{array}{c}1 \\
(7.14) \\
\end{array}$ & $\begin{array}{c}2 \\
(10.53) \\
\end{array}$ & $\begin{array}{c}2 \\
(10.53) \\
\end{array}$ & $\begin{array}{c}1 \\
(8.33) \\
\end{array}$ & $\begin{array}{c}1 \\
(5.00) \\
\end{array}$ \\
\hline Other fungi & $\begin{array}{c}2 \\
(18.18) \\
\end{array}$ & $\begin{array}{c}2 \\
(12.50) \\
\end{array}$ & $\begin{array}{c}4 \\
(28.57) \\
\end{array}$ & $\begin{array}{c}3 \\
(17.65) \\
\end{array}$ & $\begin{array}{c}5 \\
(41.67) \\
\end{array}$ & $\begin{array}{c}3 \\
(17.65) \\
\end{array}$ & $\begin{array}{c}4 \\
(30.77) \\
\end{array}$ & $\begin{array}{c}2 \\
(14.29) \\
\end{array}$ & $\begin{array}{c}5 \\
(26.32) \\
\end{array}$ & $\begin{array}{c}5 \\
(26.32) \\
\end{array}$ & $\begin{array}{c}4 \\
(33.33) \\
\end{array}$ & $\begin{array}{c}3 \\
(15.00) \\
\end{array}$ \\
\hline Total & $\begin{array}{c}11 \\
(100)\end{array}$ & $\begin{array}{c}16 \\
(100)\end{array}$ & $\begin{array}{c}14 \\
(100)\end{array}$ & $\begin{array}{c}17 \\
(100)\end{array}$ & $\begin{array}{c}12 \\
(100)\end{array}$ & $\begin{array}{c}17 \\
(100)\end{array}$ & $\begin{array}{c}13 \\
(100)\end{array}$ & $\begin{array}{c}14 \\
(100)\end{array}$ & $\begin{array}{c}19 \\
(100)\end{array}$ & $\begin{array}{c}19 \\
(100)\end{array}$ & $\begin{array}{c}12 \\
(100)\end{array}$ & $\begin{array}{c}20 \\
(100)\end{array}$ \\
\hline
\end{tabular}

*ean number of isolated colonies of 4 replicates from each location (values in first line). ${ }^{\star *}$ Percentage (inside brackets) of isolated colonies calculated by dividing number of isolated colonies on the total number of isolated colonies (values in the second line). 